\title{
Heinrich G. REICHERT, Unvergängliche lateinische Spruchweisheit: urban und human, Erzabtei St. Ottilien 1997, EOS Verlag, ss. 376.
}

Jest to już ósme wydanie, a wlaściwie przedruk ze zmienionym tytułem czwartego wydania. Fakt, ze po raz ósmy książka została wydana, świadczy o zainteresowaniu czytelników mądrością antycznych przysłów i sentencji. Książka zawiera spis jedenastu ilustracji (s. 6), które treściowo korespondują z poszczególnymi częściami lub podtytułami. Autor poprzedził swoją książkę przedmową (ss. 13-17), w której tłumaczy, że nie ma ona charakteru filologicznego, ale chce poprzez nią pośredniczyć w przekazie przysłów, popularnych powiedzeń, sentencji, zwartych i treściwych zdań w szerokim sensie (s. 13). A czyni to rzeczywiście, ukazując wielokrotnie wieloznaczność sentencji, odczuwaną już przez starożytnych Rzymian. Włącza do refleksji nad wybraną sentencją jej reminiscencje w literaturze łacińskiej, a także często jej użycie i ewentualne przeksztalcenia w chrześcijańskim średniowieczu, renesansie, w czasach nowożytnych aż po jej współczesny sposób rozumienia i użycie. Z tych sentencji płynie bardzo bliska i żywa mądrość życiowa, siła moralna, brzemienne w glębokie myśli pouczenie. Wszystko to jest jeszcze poparte autorytetem Autora i powagą wieków, w których użycie danej myśli wykrystalizowało jej brzmienie i dobór słów, które niezmiennie trwają do naszych czasów. Także i dziś, posłużenie się w wypowiedzi bogatym w treść, a niewiele słów zawierającym łacińskim przysłowiem lub powiedzeniem, świadczy o urban und human człowieka, o jego wykształceniu i humanizmie. W przedmowie Autor podkreśla także wartość greckiego i lacińskiego antyku, która przewyźsza jednak w sposób niewspólmierny chrześcijaństwo. Dokonuje również porównującego zestawienia muzykalnej greki ze skąpą łaciną: lacina jest ścisła, jasno uformowana, pełna sily i zamknięta jak rzymskie kohorty oraz konserwatywna jak lud rzymski; podczas gdy greka wyraża głębię (Tiefsinn) myśli, lacina wyraża jej ostrość (Scharfsinn). Łacina „żyje” ze słowa wyrażającego czynność, z siły, aktywności, działania, dlatego myśli szybciej i jest krótsza niż inne języki (s. 15).

Celem Autora nie było nic innego, jak tylko wywołać radość z pięknie wystylizowanej sentencji i przez to pomóc kształtować humanistyczny smak, co samo z siebie prowadzi do zastanowienia, do prawdy, do szlachetności, do piękna, a tym samym do Boga (s. 17). Treść książki podzielona jest na poszczególne części. Chociaż nie ma ona formalnego podziału na rozdziały, to Autor nadaje większym częściom tytuły, a w nich umieszcza jakby podtytuły. Wszystkie tytuły i podtytuły poszczególnych części zawierają sentencję lub powiedzenie, które stanowi osnowę rozważań dla Autora. W każdej części i podtytule Autor, snując refleksje na temat danego przysłowia, umieszcza wiele słynnych cytatów i popularnych powiedzeń.

Pierwsza część książki nosi tytuł Rom (Rzym - ss. 19-40), z podtytułem Vom Glanze Roms (O wspaniałości Rzymu), gdzie na kanwie cytatu z Ars 
amatoria (I 174) Owidiusza „Ingens orbis in Urbe fuit”, Autor snuje rozważania o wielkości Rzymu; przy rozważaniach o początkach Rzymu i jego burzliwych losach przez wieki, posłużył się wersem "Roma quadrata, Roma aurea" z Contra Symmachum (II 1114) Prudencjusza; następne tytuły mówią o wiecznym Rzymie, gdzie Autor przytacza wiele fragmentów z literatury rzymskiej, o Rzymie chrześcijańskim pisze obszernie przytaczając cytaty z Pisma św., a także wielu autorów łacińskich (Augustyna, Prudencjusza), włączając i innych późniejszych - Dantego, Rabelego, Goethego, snując rozważania o wielkości Rzymu i papiestwa; krótko mówi o legendarnych początkach Rzymu i jego posłannictwie, przytaczając słowa „Parcere subiectis et debellare superbos"; w podtytule o pierwotnym Kościele w Rzymie umieszcza znane nam $\mathrm{z}$ apokryfów a później z powieści Henryka Sienkiewicza słowa legendy „Domine, quo vadis?", snując rozważania o pobycie św. Piotra w Rzymie.

Druga część nosi tytuł Römisches Recht (Prawo rzymskie - ss. 41-63), a podtytul Vom römischen Bürgerstolz (O rzymskiej dumie obywatelskiej), ilustrowany jest słowami św. Pawła „Civis Romanus sum”; zaraz potem dość dużo miejsca poświęca rzymskiej definicji sprawiedliwości sformułowanej przez Ulpiana Suum cuique, pisząc przy tym, jak się wydaje z lekką przesadą, że rzymski chłop około 500 r. przed Chr. bardziej był zorientowany w prawie, niż dzisiejszy przeciętny Europejczyk (s. 43).

Kolejną rzymską zasadę sformułowaną przez Cycerona (De legibus III 3 , 8): „Salus publica suprema lex", ilustruje w rozważaniach wieloma prawniczymi, filozoficznymi i literackimi zdaniami: „Duo cum faciunt idem, non est idem" (Terentius, Andria 823, „In dubio pro reo; Actum ne agas” (Terentius, Phormio 419). Zasada prawna „Audiatur et altera pars” jest omawiana oddzielnie. Podtytul o granicach prawa ilustruje powiedzeniem Cycerona „Summum ius, summa iniuria”. W rozważaniach Autor przytacza wiele sentencji o sprawiedliwości i niesprawiedliwości, kończąc je zasadą sformułowaną przez św. Tomasza: „Bonum commune est melius quam bonum unius” (Summa theologica II 2, quest. 47).

W części poświęconej rzymskim postaciom (Römische Gestalten - ss. 64-94), na pierwszym miejscu umieszcza Cycerona, a jako punkt wyjścia dla rozważań o nim podaje zdanie „Pectus est quod facit disertos”. Następną osobą, którą Autor umieszcza w panteonie rzymskich postaci jest Cezar. Mottem dla opisu jego osoby są słowa Swetoniusza o Cezarze „Nam Caesari multos Marios inesse". Kolejne postacie to augurowie i wieszcze. Rozważania nad ich funkcją w spoleczeństwie rozpoczyna Autor od zdania Cycerona z: „Mirari, quod non ridet haruspex" (De divinatione II 24,51). W podtytule o plaszczu królewskim i cierniowej koronie, który rozpoczyna zdaniem Seneki: „Aut regem aut fatuum nasci oportet" (Apocolocyntosis 1), rozważa rolę Piłata i rzymskich żołnierzy przy ukrzyżowaniu Chrystusa. Zauważa jednak przy tym, że w literaturze rzymskiej nie ma przykładów żartów, lub naśmiewania się z kapłanów i żołnie- 
rzy. Chrystus nie jest wyszydzany przez żadnego z epigramatyków czy satyryków (s. 83). Krótko wspomina o Żydach w twórczości Horacego, w oparciu o jego zdanie z satyr: "Credat Iudaeus Apella” (Sat. I 5, 100). Podobnie traktuje stoicyzm, przytaczając stowa popełniającej samobójstwo Arrii wypowiedziane do swego męża: „Non dolet, Paete”. Omawiając zaś wielkość Pliniusza Młodszego przytacza jego adagium z listów: „Multum, non multa” (Epistulae VII 9, 15), w którym zawarł radę, jak należy czytać książki. Tę część kończy Autor refleksją nad postacią „gorliwca” Tertuliana, a jako motto do rozważań umieszcza jego zdanie „Faciunt favos et vespae” (Adversus Marcionem IV 5); posługując się tym przysłowiem Tertulian walczył z Marcjonem i jego nauką.

Kolejna część książki nosi tytuł Mächte (Siły - ss. 95-176). Pierwszy podtytuł o przyrodzie rozpoczyna zdanie Cycerona: „Omnium rerum principia parva sunt" (De finibus bonorum et malorum V 21). Dalsze przystowie, nad którym Autor snuje refleksje, to zdanie Owidiusza z jego Listów z Pontu (IV 10,5): "Gutta cavat lapidem”, którego druga część „consumitur anulus usu”, została przez nieznajomego Autora zmieniona na "non vi sed semper cadendo". O przyzwyczajeniu jako drugiej naturze rozważa w podtytule Secunda natura (Augustinus, Contra Iulianum IV 103). W podtytule o czasie: „Tempus edax rerum" (Ovidius, Metamorphoses XV 235), rozważa siłę czasu i przemijania. Umieszcza w nim wiele słynnych zdań: „Tempora mutantur nos et mutamur in illis”; „Omnes vulnerant, ultima necat”. W kolejnym podtytule tej części, o dążeniu człowieka do upodobnienia się do Boga, cytuje zdanie z Księgi Rodzaju (3, 5): „Eritis sicut Deus scientes bonum et malum”. Refleksje nad Ojcze nasz pełne są również cytatów z literatury łacińskiej o ważności chleba w życiu czlowieka. Ukazuje przy tym sposób traktowania chleba przez narody starożytne oraz snuje piękne rozważania o Eucharystii.

Mówiąc o kolejnej sile, jaką jest miłość, cytuje wielu autorów łacińskich. Podstawą refleksji jest tu cytat z Bukolik Wergiliusza (X 69): „Omnia vincit amor”. Stynne zaś zdanie Augustyna: „Ama et fac quod vis” uzupełnia uwagą, że prof. dr Jörg Splett zauważył, iż Biskup Hippony powiedział w Komentarzu do 1 Listu św. Jana: „Dilige et quod vis fac”; przeciwieństwem amare jest odisse, a przeciwieństwem diligere jest neglegere (s. 127 i 349). Wiele też innych przysłów o miłości z literatury rzymskiej i greckiej włącza do tych rozważań rozpoczynając od zdania Seneki: „Si vis amari ama” (Epistulae 9,6). Inną „siłą” jest przyjaźń. Rozważając o niej (ss. 135-140) przyjmuje jako motto, definicję Arystotelesa, przejętą przez Salustiusza: „Idem velle atque idem nolle" (De coniuratione Catilinae 20,4). O zgubnej i jednocześnie pożytecznej „sile", jaką jest pieniądz, rozważa z kolei w podtytule o pieniądzu (ss. 141-148), który nazywa Nervus rerum.

Wiele przysłów z Biblii i literatury przytacza w podtytule $O$ rodzajach kobiet (ss. 155-168): „Genus mutabile mulierum”, „Ubi tu Gaius, ibi ego 
Gaia”, „Mulier taceat in Ecclesia” - to tytuły poszczególnych fragmentów rozważań. Odniesienie Chrystusa do kobiet i piękno Maryi stanowią, według Autora, zupełne przeciwieństwo w odnoszeniu się do kobiet calego świata grecko-rzymskiego. Tę część książki kończą refleksje Autora $O$ pokoju (ss. 169-176), które przeplata wieloma powiedzeniami i cytatami o pokoju i wojnie: „Pax Cererem nutrit, pacis alumna Ceres” (Ovidius, Fasti 1, 704); „Pax est tranquillitas ordinis" (Augustinus, De civitate Dei 19, 15).

Najobszerniejsza jest ta część książki, której Autor dał tytuł Ideen (Idee ss. 177-300). W tej części pisze o historiografii (Arduum est res gestas scriberess. 177-181), o poezji (Volat avis sine meta quo nec vates nec propheta evolavit altius - ss. 182-191), o filozofii (Felix qui potuit rerum cognoscere causas, Vergilius, Georg. II 490 - ss. 192-196), o badaniach naukowych (Vitam impendere vero, Juvenalis, Satyrae 4, 91 - ss. 197-200), o sposobie życia (Carpe diem, Horatius, Carmina I 11, 8 - ss. 201-202), o wiedzy i humanitas (Legere enim et non intellegere neglegere est -ss. 204-228), o medycynie (Medicus curat, natura sanat - ss. 229-241), o nieśmiertelności (Non omnis moriar, Horatius, Carmina III 30 - ss. 242-251), o ostatnim Rzymianinie Boecjuszu (Nihil ex nihilo, Boethius, De consolatione philosophiae V 1) i o wyrzeczeniu się świata (Ora et labora - ss. 252-268), o wierze i wiedzy (Credo ut intellegam, Anselmus Cant., Proslogion 1); do tych ostatnich włącza wielu myślicieli: Kopernika, Marcina Lutra, Kartezjusza, Spinozę, Leibniza (ss. 271-289).

W ostatniej części książki, zatytułowanej Alltag (Codzienność - ss. 301349), Autor mówi o rzymskim lustrum, o słusznej mierze (Est modus in rebus, Horatius, Sermones I 1, 106), o zaczynaniu opowiadań ab ovo, o tradycji ludowej, o wartości malarstwa, o zemście rzeczy martwych (koń trojański), o odgrzewanych kartoflach (jako powtarzaniu tego samego), o wielu przystowiach związanych z lwami (Hic sunt leones, Societas leonina, Pars leonis, Unum, sed leonem), o przeklętym głodzie złota (Auri sacra fames), o godności (Cui honorem, honorem), o konieczności pisania satyr, tę część książki, i całą książkę, kończy podtytułem Święci i poeci (Non coerceri maximo, contineri tamen a minimo divinum est).

Do tego wydania książki został dołączony indeks osób z podaniem lat, w których żyli (ss. 350-351), oraz alfabetyczny spis łacińskich sentencji (ss. 352-362), a na końcu alfabetyczny spis tychże sentencji w thumaczeniu na język niemiecki (ss. 363-376).

Książka Reicherta jest wyrazem tęsknoty czlowieka za szukaniem duchowego osiedlenia się w szlachetnym i trwałym świecie, gdy wkoło wszystko łamie się i upada. Tym światem jest humanitas. Autor zawarł w swojej książce jakby historię humanitas, wyrażoną w mądrości przysłów i słynnych powiedzeń. Ich liczba jest niezwykle duża, a ich treść trwała i po wielu wiekach niezmienna. Wszyscy korzystamy z antycznego, greckiego i rzymskiego dobra duchowego. Powinniśmy je tak, jak poprzednie wieki, zachować, z szacunkiem odnowić 
i przekazać następnym pokoleniom. Książka jest ze wszech miar godna polecenia tym wszystkim, którzy cenią język łaciński, literaturę antyczną, średniowieczną i nowożytną oraz zawartą w niej nieprzemijającą mądrość łacińskich przysłów i powiedzeń.

Ks. Krzysztof Burczak - Lublin

Stephan WENINGER, Das Verbalsystem des Altäthiopischen. Eine Untersuchung seiner Verwendung und Funktion unter Berücksichtigung des Interferenzproblems (Veröffentlichungen der Orientalischen Kommission der Akademie der Wissenschaften und der Literatur im Mainz, hrsg. Walther W. Müller, Bd. 47), Wiesbaden 2001, Harrassowitz Verlag, ss. 387.

Omawiana książka jest poprawioną wersją rozprawy habilitacyjnej S. Weningera z 1997 r. na Uniwersytecie Ludwika Maksymiliana w Monachium. Autor po raz pierwszy zastosowal w niej metodę lingwistyczno-noetyczną, wypracowaną przez ośrodek monachijski po II wojnie światowej, dzięki pracom E. Koschmidera i A. Denza, nad klasycznym językiem etiopskim geez. W latach siedemdziesiątych ubiegłego wieku semitolog Adolf Denz na podstawie prac E. Koschmidera zastosował metodę noetyczną do dialektu języka arabskiego zwanego Kwayrisz, a jego uczniowie do innych języków semickich: R. Bartelmus zastosował ją do języka hebrajskiego i aramejsko-biblijjnego, N. Nebes i Ch. Correll do języka arabskiego, M. Streck do języka akkadyjskiego, a S. Bombeck do języka syryjskiego.

$\mathrm{Na}$ czym polega owa nowa metoda językoznawcza (Die Methode der noetischen Sachverhaltsanalyse) (ss. 24-36) wypracowana przez ośrodek monachijski? Metoda ta polega w skrócie na badaniu relacji i czynności jakie zachodzą wobec aktualnego punktu odniesienia mówiącego, który może istnieć w czasie teraźniejszym, przeszłym i przyszłym. Należy tu również wziąć pod uwagę aspekt czynności - dokonany lub niedokonany. Wyróżnia się na przykład jednostkowe i ogólne rodzaje czynności (individuelle, generelle Sachverhalte). Czynności jednostkowe dzielą się na jednorazowe i wielokrotne, które w zależności od czasu mogą być współczesne, przeszłe i przyszłe.

Metodę noetycznej analizy czynności zastosował Weninger do 13 kategorii czasownikowych: qatala, yekattel, yektel, qatilo, qetel, hallo yeqtel, hallawa teqtel, hallo qatilo, kona qatala, kona.yekattel, nabara yekattel, nabara qatilo. Przykłady obrazujące zastosowanie metody noetycznej do wymienionych kategorii czasownikowych zaczerpnął Weninger ze Starego i Nowego Testamentu oraz etiopskiej literatury patrystycznej. Wyniki swych badań przedstawił w czwartym rozdziale Funktionsanalyse (ss. 309-336), z którego dowiadujemy się, jak omawiana kategoria czasownikowa funkcjonuje w świetle analizy noe- 